\title{
Form and function of the apical extracellular matrix: new insights from Caenorhabditis elegans, Drosophila melanogaster, and the vertebrate inner ear
}

\author{
Sherry Li Zheng (iD 1,2 Jennifer Gotenstein Adams ${ }^{2}$ Andrew D. Chisholm (D) 2* \\ ${ }^{1}$ Department of Developmental Biology, Stanford University School of Medicine, Stanford, CA 94305, USA \\ ${ }^{2}$ Section of Cell and Developmental Biology, Division of Biological Sciences, University of California San Diego, La Jolla, CA 92093, USA
}

\begin{abstract}
Apical extracellular matrices (aECMs) are the extracellular layers on the apical sides of epithelia. aECMs form the outer layer of the skin in most animals and line the luminal surface of internal tubular epithelia. Compared to the more conserved basal ECMs (basement membranes), aECMs are highly diverse between tissues and between organisms and have been more challenging to understand at mechanistic levels. Studies in several genetic model organisms are revealing new insights into aECM composition, biogenesis, and function and have begun to illuminate common principles and themes of aECM organization. There is emerging evidence that, in addition to mechanical or structural roles, aECMs can participate in reciprocal signaling with associated epithelia and other cell types. Studies are also revealing mechanisms underlying the intricate nanopatterns exhibited by many aECMs. In this review, we highlight recent findings from well-studied model systems, including the external cuticle and ductal aECMs of Caenorhabditis elegans, Drosophila melanogaster, and other insects and the internal aECMs of the vertebrate inner ear.
\end{abstract}

\section{Keywords}

epithelia, collagens, zona pellucida domain, chitin, tubulogenesis

\section{Peer Review}

The peer reviewers who approve this article are:

1. Andrew K. Groves, Department of Molecular and Human Genetics, Baylor College of Medicine, Houston, TX, USA Competing interests: No competing interests were disclosed.

2. Meera V. Sundaram, Department of Genetics, University of Pennsylvania Perelman School of Medicine, Philadelphia, PA, USA

Competing interests: No competing interests were disclosed. 
*Corresponding author: Andrew D. Chisholm (adchisholm@ucsd.edu)

Competing interests: The authors declare that they have no competing interests.

Grant information: Work in our laboratory on the C. elegans ECM is supported by the NIH (R35 GM134970). S.L.Z. was supported by a UC San Diego Triton Research and Experiential Learning Scholarship and the UC San Diego Gabriele Wienhausen Biological Sciences Scholarship.

The funders had no role in study design, data collection and analysis, decision to publish, or preparation of the manuscript.

Copyright: (C) 2020 Chisholm AD et al. This is an open access article distributed under the terms of the Creative Commons Attribution License, which permits unrestricted use, distribution, and reproduction in any medium, provided the original work is properly cited.

How to cite this article: Zheng SL, Adams JG and Chisholm AD. Form and function of the apical extracellular matrix: new insights from

Caenorhabditis elegans, Drosophila melanogaster, and the vertebrate inner ear. Faculty Reviews 2020 9:(27) https://doi.org/10.12703/r/9-27

Published: 22 Dec 2020, Faculty Reviews 9:(27) https://doi.org/10.12703/r/9-27 


\section{Introduction}

The extracellular matrix (ECM) is the network of collagens, proteoglycans, lipids, enzymes, and other components that surround cells. These networks provide structural and biochemical support to cells and tissues and are involved in the communication between a cell and its external environment, including surrounding cells. The ECM plays critical roles in many developmental processes, including tissue homeostasis, differentiation, and morphogenesis in all animals ${ }^{1}$. ECMs can be classified as apical, basal, or stromal. Basal ECMs, also known as basal laminae or basement membranes, are universal and ancient features of animal epithelia ${ }^{2}$ and contain conserved core proteins such as laminins and type IV collagens. In contrast to basal and stromal ECMs, which serve specialized functions on the interior sides of tissues, apical ECMs (aECMs) act as barriers along the outer surfaces of epithelial tissues such as the skin or internal tubular organs. External aECMs, such as the cuticle of nematodes and arthropods, are highly specialized for their ecological niches yet share common features such as regulation by matrix crosslinking enzymes. External aECMs can incorporate lipid layers that provide desiccation resistance and permeability barrier function. Internal aECMs, such as those of tubular epithelia, often have transient developmental roles in shaping tube morphology $y^{3,4}$. Other aECMs found in vertebrates include the vascular glycocalyx, the mucin-rich coating of the gastrointestinal tract and upper airways, and the alveolar surfactant of lungs. Compared to the conserved basal ECM, aECMs are diverse in composition and function but contain major conserved families such as collagens, lectins, and mucin-related glycoproteins (Table 1). Proteins with zona pellucida (ZP) domains ${ }^{5}$ are associated with early stages of aECM formation in multiple model systems, while the rigidity of external aECMs is often provided by layers of the amino polysaccharide chitin. Here we review recent advances in understanding the biosynthesis, patterning, and signaling roles of selected model aECMs.

\section{Caenorhabditis elegans aECM components and biosynthesis}

As the outermost layer of $C$. elegans skin, the cuticle is an accessible model for studies of aECMs. The $C$. elegans epidermis (known as the hypodermis) secretes a complex multilayered aECM beginning in late embryogenesis and thereafter in four molts, resulting in the mature adult cuticle consisting of an outer surface coat, a lipid-rich epicuticle, and the multilayered collagenous cuticle (Figure 1a) (6-8 $^{6}$. Other epithelial aECMs in C. elegans include those of internal tubes, such as the excretory duct and vulva, and specialized aECMs of sensory organs ${ }^{4,9}$. Recent bioinformatic analysis has enumerated components of the C. elegans ECM (including aECMs), predicting a total "matrisome" of over 700 proteins ${ }^{10}$. The 43 C. elegans ZP proteins have been further classified by phylogenetic methods ${ }^{11,12}$. This "parts list" for C. elegans aECMs remains dauntingly complex, with functional or expression data lacking for many proteins.

One longstanding question remains: how do complex aECM structures assemble, starting in the secretory pathway and concluding in the extracellular space? Elegant genetic screens identified the conserved protein family TMEM131 as being important for ER processing of cuticle collagen $\operatorname{cargos}^{13}$; TMEM131 may directly interact with collagens. Interestingly, TMEM131 function in collagen biosynthesis appears to be conserved, despite low sequence conservation between nematode cuticle collagens and collagens in other organisms. Despite their molecular diversity, aECMs may share common factors in their biogenesis.

Just over $10 \%$ of the 180 C. elegans cuticle collagens were identified in classical phenotype-based screening. Loss or gain of function in certain cuticle collagens can have dramatic effects on body morphology, leading to phenotypes such as dumpy (Dpy), long (Lon), roller (Rol), or blistered (Bli); the lack of functional information on other collagens may reflect genetic redundancy. A recent report found that the laboratory "wildtype" strain (N2) accumulated a loss-of-function mutation in the collagen col-182 that affects the phenotypes caused by other collagen mutations ${ }^{14}$. The standard wild-type strain itself may be sensitized to alterations in cuticle function compared to the ancestral C. elegans.

The first embryonic epidermal aECM, known as the pre-cuticle or embryonic sheath, precedes the collagenous cuticle and is essential for epidermal morphogenesis. The pre-cuticle contains multiple ZP-domain proteins including FBN- $1^{15}$, NOAH-1, and NOAH- $2^{16}$, as well as extracellular leucine-rich repeat proteins $^{17}$ and lipocalins ${ }^{18}$. The nidogen- and EGF-domain transmembrane protein DEX-1 localizes to multiple aECMs; dex-1 loss-of-function mutants resemble multiple ZP mutants, suggesting that DEX-1 may act together with one or more ZP proteins $^{12}$. DEX-1 itself is upregulated in response to starvation and is required for structural and functional remodeling of the cuticle during the dauer stage ${ }^{19}$. Subsets of ZP-domain proteins or their interacting partners may contribute to the unique characteristics of other aECMs, such as those of the excretory canal lumen, sensory organs, or the vulva lumen ${ }^{9,20}$. Interestingly, many of these aECMs play transient developmental roles in the initial establishment of an aECM.

Comparatively little remains known of the biogenesis or function of the lipid-rich epicuticle, which shares some ultrastructural similarities with lipid bilayers. Alterations in surface lipid composition have been linked to defects in cuticle integrity ${ }^{21}$ and resistance to surface bacterial infections ${ }^{22}$. In C. elegans, lipid-binding lipocalins LPR-1 and LPR-3 are required for normal surface lipid organization and may play roles in transport or localization of aECM lipids to the epicuticle ${ }^{18}$.

\section{The aECM as a signaling center: interactions between the $C$. elegans cuticle and other cells}

Emerging evidence has revealed complex interactions between the cuticle and the epidermis. Many cuticle collagens are upregulated during the synthesis of new cuticle during embryogenesis and/or the four post-embryonic molts; within each molt, collagen transcription is precisely timed (within 1-2 hours) to 


\begin{tabular}{|c|c|c|c|c|}
\hline Protein family or role & $\begin{array}{l}\text { Caenorhabditis } \\
\text { elegans }\end{array}$ & Drosophila melanogaster & Vertebrates & References \\
\hline Collagens & $\begin{array}{l}\text { COL-182 } \\
\text { BLI-1 }\end{array}$ & & $\begin{array}{l}\text { Collagens II, V, IX, } \\
\text { and XI }\end{array}$ & $\begin{array}{l}14,23 \\
2\end{array}$ \\
\hline Collagen processing & TMEM-131 & & & 13 \\
\hline Transcription factors & $\begin{array}{l}\text { LIN-29 } \\
\text { ELT-3 }\end{array}$ & $\begin{array}{l}\text { Blimp-1 } \\
\text { Yorkie (YAP/TAZ) } \\
\text { Ichor } \\
\text { Ubx }\end{array}$ & & $\begin{array}{l}23,24 \\
25-28\end{array}$ \\
\hline ZP domains & $\begin{array}{l}\mathrm{FBN}-1 \\
\mathrm{NOAH}-1 \\
\mathrm{NOAH}-2\end{array}$ & $\begin{array}{l}\text { Dumpy (Dp) } \\
\text { Piopio (Pio) } \\
\text { NompA } \\
\text { Trynity (Tyn) }\end{array}$ & $\begin{array}{l}\alpha \text {-tectorin (TECTA) } \\
\beta \text {-tectorin (TECTB) }\end{array}$ & $\begin{array}{l}15,16 \\
3,12,29 \\
30,31\end{array}$ \\
\hline Nidogen + EGF & DEX-1 & & $\alpha$-tectorin (TECTA) & $\begin{array}{l}12,19 \\
30,31\end{array}$ \\
\hline eLRRon & $\begin{array}{l}\text { LET-4, EGG-6, } \\
\text { SYM-1 }\end{array}$ & Artichoke & & $\begin{array}{l}17 \\
32\end{array}$ \\
\hline $\begin{array}{l}\text { Extracellular signaling } \\
\text { pathways }\end{array}$ & $\begin{array}{l}\text { DAF-7/TGF } \beta \\
\text { DBL-1/BMP } \\
\text { NPR-8 }\end{array}$ & & & $33-36$ \\
\hline $\begin{array}{l}\text { ABC transporters + } \\
\text { related }\end{array}$ & & $\begin{array}{l}\text { Snustorr (Snu) } \\
\text { Oskyddad (Osy) } \\
\text { Snu-like (Snsl) }\end{array}$ & $\mathrm{ABCA} 12$ & $\begin{array}{l}37,38 \\
39\end{array}$ \\
\hline Osiris & & Gore-tex (Gox) & & 40 \\
\hline $\begin{array}{l}\text { Chitin biosynthesis/ } \\
\text { deposition }\end{array}$ & & $\begin{array}{l}\text { Obstructor-A (ObstA) } \\
\text { Expansion (Exp) } \\
\text { Rebuff (Reb) } \\
\text { Apnoia (Apn) }\end{array}$ & & $3,41-43$ \\
\hline C-type lectin & & Schlaff (SIf) & & 44 \\
\hline Crosslinking enzymes & & Alas & & 26 \\
\hline Proteases & & $\begin{array}{l}\text { Lumens interrupted (Lint) } \\
\text { Notopleural (Np) } \\
\text { Tracheal-prostasin (Tpr) }\end{array}$ & & 27,45 \\
\hline Glycoproteins & & & $\begin{array}{l}\text { Otogelin (OTOG) } \\
\text { Otogelin-like (OTOGL) } \\
\text { Otoancorin } \\
\text { Stereocilin }\end{array}$ & 30,46 \\
\hline
\end{tabular}

Only selected proteins are shown owing to limitations of space.

coincide with the cuticle layer being secreted ${ }^{47}$. Cuticle collagens are also regulated by transcriptional pathways that control the developmental progression of stages; for example, multiple collagens are activated by the zinc finger transcription factor LIN-29, which coordinates the larval-to-adult switch. LIN-29 and its collagen targets are also upregulated in response to loss of function in the collagen BLI-1, a model of cuticle damage ${ }^{23}$, suggesting that collagen expression by the epidermis is subject to feedback regulation to maintain cuticle integrity. Disruption of collagens localized to annular furrows triggers specific stress or antimicrobial responses, suggesting furrows are required for sensing environmental conditions ${ }^{48}$. Conversely, cuticle composition may be regulated by environmental conditions such as nutrition or population density, possibly via the epidermal GATA factor ELT- $3^{24}$.

Molting involves the loss of a cuticle layer and its replacement by a new, distinct layer. New findings suggest that the disruption 
a. C. elegans cuticle

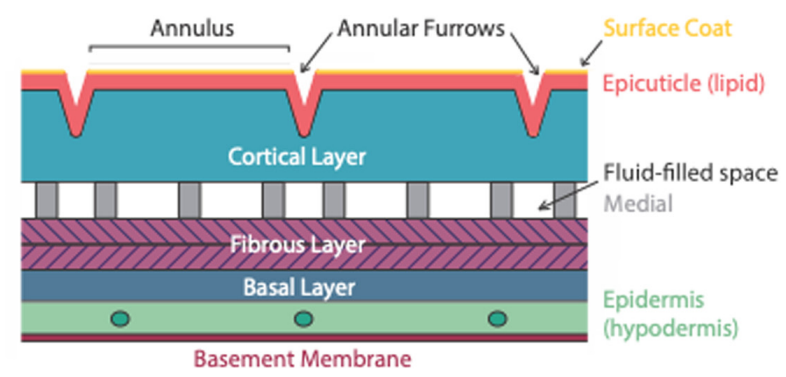

c. D. melanogaster tracheal tube

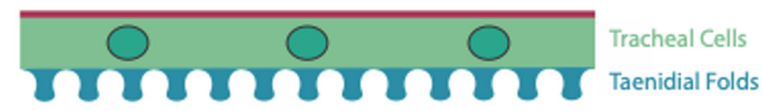

Gas-filled space

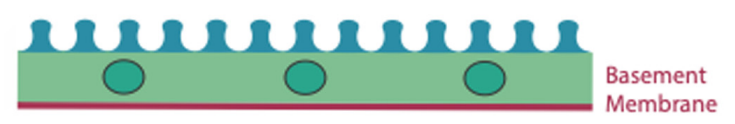

b. D. melanogaster cuticle

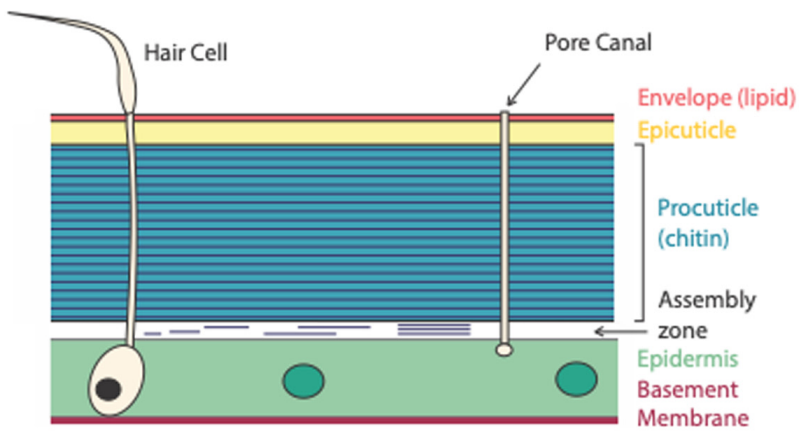

Figure 1. Apical extracellular matrices of Caenorhabditis elegans, Drosophila melanogaster, and the vertebrate inner ear. a. Cartoon of adult $C$. elegans cuticle, longitudinal section. The cuticle consists of an outer surface coat (gold), a lipid-rich epicuticle (red), collagenous cuticle proper (divided into cortical [blue], medial [gray], fibrous [purple], and basal [navy] layers). The cuticle is secreted by the underlying cellular epidermis (green), internal to which is a basement membrane (burgundy). b. Cartoon of $D$. melanogaster cuticle, consisting of an outer lipid-rich envelope (red), glycoprotein-rich epicuticle (yellow), and the chitinous procuticle (blue), formed in the assembly zone at the apical surface of the underlying epidermis (green). Pore canals form channels through the cuticle layers to the surface. c. Cartoon of D. melanogaster mature tracheal cuticle, showing taenidial folds (blue). Envelope and epicuticle are not shown for simplicity. $\mathbf{d}$. The vertebrate tectorial membrane (blue) is shown in cross section, attached to the underlying epithelial ridge of the organ of Corti at its medial edge and to the stereocilia of the outer hair cells at its lateral edge. The underlying basement membrane is known as the basilar membrane.

of contacts between the epidermis and cuticle may trigger transcriptional activation of epidermal lysosome function ${ }^{49}$. "Activated" lysosomes appear to degrade components of the old cuticle, possibly generating raw materials for fresh cuticle synthesis. Loss of function in specific cuticle collagens increases autophagy in the epidermis, dependent on the ciliary transport function of ASI sensory neurons and the TGF $\beta$ signal DAF- $7^{33}$. Ciliated sensory neurons contact parts of the epidermis and cuticle and might sense cuticle integrity directly or indirectly. These studies also suggest overlap between molting pathways and factors involved in damage sensing in the mature epidermis.

The integrity or function of the cuticle may also be sensed by other tissues, implying complex systemic regulation of cuticle composition and function. For example, altered collagen levels can affect the level of the neuronally expressed BMP signal DBL- ${ }^{34}$, which acts via SMADs in the epidermis to regulate cuticle collagen expression ${ }^{35}$. These observations suggest the operation of a feedback pathway that senses cuticle function; the precise mechanism of such feedback is not yet clear but could involve mechanosensing by neurons. Cuticle collagen synthesis is also inhibited by the neuronally expressed neuropeptide receptor NPR-8, leading to elevated Pseudomonas resistance of $n p r-8$ mutants $^{36}$. How neuronal NPR- 8 affects collagen expression also remains to be determined.

\section{The aECM of the Drosophila melanogaster cuticle and trachea}

Like the nematode cuticle, the D. melanogaster cuticle is layered and serves a protective role but is more rigid and highly pigmented; D. melanogaster also produces specialized aECMs for sensory organs, appendages, and organ tube formation. The D. melanogaster cuticle, like that of most insects, contains three major layers: the lipid-rich envelope, protein-rich epicuticle, and a chitinous procuticle (Figure 1b). The procuticle provides mechanical strength, while the envelope has a barrier function. 
Recent work has shed light on the formation of the lipid-rich envelope. The ZP-domain protein Trynity (Tyn) is required for epidermal barrier function; ultrastructural analysis indicates Tyn is specifically required for the lipid envelope ${ }^{29}$. The envelope also contains cuticulin, a complex waterproof molecule composed of protein, lipid, and catecholamine. Cuticulin deposition requires nanopore canals connecting the apical epidermis to the exterior cuticle. The ABC transporter Snustorr (Snu) localizes to the apical plasma membrane and transport vesicles and is required for cuticulin and lipid deposition to the envelope $^{37}$. The secreted Snu-like protein (Snsl) is also required for proper cuticulin deposition and localizes to pore canals, dependent on $\mathrm{Snu}^{37}$. Another $\mathrm{ABC}$ transporter, Oskyddad (Osy), localizes to pore canals and is required for transport of cuticular hydrocarbons to the cuticle surface ${ }^{38}$. Unlike Snu, Osy mutants do not affect envelope integrity, and Osy and Snu independently localize, suggesting that Osy and Snu act in parallel to establish the envelope barrier ${ }^{38}$. ABC transporters such as ABCA12 have also been implicated in the biogenesis of lipid-rich components of vertebrate aECM such as keratinocyte lamellar bodies and pulmonary surfactant, suggesting possible molecular similarities in extracellular lipid-based aECM formation ${ }^{39}$.

Nanopores in the cuticle of olfactory sensilla allow odorants to reach neurons while blocking large molecules and preventing significant fluid $\operatorname{loss}^{40}$. Ultrastructural analysis indicates that cells initially form electron-dense protrusions (plasma membrane plaques) which provide a scaffold for the assembly of cuticle envelope from envelope segments, thereby forming a nanopore. The Osiris family transmembrane protein Gore-tex (Gox) localizes to intracellular vesicles during cuticle secretion and may regulate trafficking of envelope components or patterning of endocytic or exocytic activity ${ }^{40}$.

Cuticle assembly occurs at the epidermal apical plasma membrane in the "assembly zone" (Figure 1b), where chitin fibers are organized into sheets (laminae) by enzymes and structural proteins including chitin synthase, chitin deacetylases, chitin-associated proteins (e.g. Obstructor-A/ObstA), ZP-domain proteins (Dumpy/Dp and Piopio/Pio), and chitinases ${ }^{3}$. Stabilization of the cuticle depends on crosslinks mediated by catecholamines, glutamine-lysine bridges, and dityrosines. The C-type lectin Schlaff (Slf) is required for cuticle compactness and appears to promote dityrosine-mediated adhesion between the epicuticle and procuticle layers ${ }^{44}$. Studies in other insects are also revealing how the fine structure of the chitinous aECM may be regulated. In the locust Locusta migratoria, chitin orientation is under circadian control, with unidirectional fibers forming during the day and helicoidal (left-twisting) fibers at night $^{50}$. Day microvilli are oriented such that chitin fibers are secreted into the assembly zone in their final orientation, whereas night fibers are secreted then self-assembled into the final helicoidal structure ${ }^{51}$. This work suggests that fine aECM structure may be determined by the regulated interplay of templating on cellular structures and extracellular self-assembly mechanisms.

\section{Tracheal tube morphogenesis and the $D$. melanogaster aECM}

Respiration in D. melanogaster is mediated by tracheal tubes, which extend from the cuticle and ramify through the body. The aECM of the trachea forms in two phases: first, a central chitin filament forms along the tracheal lumen and promotes tube expansion at the expense of tube elongation, then this filament is degraded and cuticle ridges (taenidial folds) (Figure 1c) form in a supracellular helix that extends along the trachea. The regular spacing of these taenidial folds is thought to involve self-organizing processes in the cortical actin cytoskeleton of the tracheal epithelium ${ }^{52}$ as well as feedback regulation between the cytoskeleton and the $\mathrm{aECM}^{53}$. As tracheal aECM has been extensively reviewed ${ }^{3,53,54}$, we highlight selected recent insights.

Multiple transcription factors regulate the expression of aECM components and enzymes for normal tracheal tube morphogenesis, and, as in $C$. elegans, some appear to be under feedback control by cuticle integrity or function. Multiple aECM regulators are repressed by Blimp- $1^{25}$, whose activity may be regulated by the feedback mechanism that regulates taenidial spacing ${ }^{53}$. The Hippo pathway transcription factor Yorkie (YAP/TAZ) has a dual role in tracheal morphogenesis, promoting tube elongation via the expression of cytoskeletal factors, and promoting water tightness via expression of the crosslinking enzyme Alas $^{26}$. YAP/TAZ signaling may coordinate the regulation of tracheal cytoskeletal dynamics and the aECM. Finally, the zinc finger protein Ichor is required for correct lumen shaping in the seamless tubes of terminal tracheal branches ${ }^{27}$ and promotes the transcription of multiple aECM regulators or components, including members of the Osiris family and the serine protease Lumens Interrupted (Lint) ${ }^{27}$.

Tracheal chitin deposition requires chitin synthase and two related proteins, Expansion (Exp) and Rebuff (Reb) $)^{41}$ Reb mutants display slightly reduced luminal chitin and severely reduced luminal chitin-binding protein ObstA, leading to overall reduced $\mathrm{aECM}^{42}$. Reb and Exp contain $\mathrm{MH} 2$ domains also found in SMAD proteins but are thought to act independently of canonical TGF $\beta$ signaling; Reb may be required for normal endocytosis or recycling of ObstA or other components ${ }^{42}$. Apnoia (Apn), a novel transmembrane protein localized to the apical side of the tracheal lumen, is required for normal tube length and aECM deposition and may be involved in vesicular trafficking of tracheal $\mathrm{aECM}^{43}$. Tracheal $\mathrm{aECM}$ is degraded and removed in a coordinated wave of endocytosis ${ }^{55}$, but how aECM is rapidly cleared from the lumen remains to be fully understood. Pore-like taenidial channels between the taenidial folds likely control the passage of aECM to the apical plasma membrane for endocytosis ${ }^{29}$. As well as having defective epidermal barrier function, Tyn mutants display aberrant taenidial channels, likely impairing endocytic clearance of luminal aECMs and resulting in defective gas filling of the trachea ${ }^{29}$. The matriptase-related protease Notopleural (Np) is also essential for liquid clearance and gas filling of the tracheal tubes ${ }^{45}$. $\mathrm{Np}$ mutant embryos have normal chitin deposition and 
clearance but develop an unstructured aECM lacking taenidial folds. $N p$ mutants deposit $\mathrm{Dp}$ in the aECM but are blocked in $\mathrm{Dp}$ condensation or degradation ${ }^{45}$. Targets of $\mathrm{Np}$ cleavage include the protease tracheal-prostasin (tpr) and another ZP protein, $\mathrm{Pio}^{45}$, suggesting conservation of the matriptase-prostasin proteolytic cascade between vertebrates and D. melanogaster.

\section{D. melanogaster appendage morphogenesis involves dynamic regulation of the $\mathrm{aECM}$}

Recent findings highlight the critical role aECMs play in morphogenesis in external appendages such as legs, wings, and halteres. Epithelial cells undergo three-dimensional shape changes to drive morphogenetic cell height expansion of the apical surface of the D. melanogaster wing and $\operatorname{leg}^{56}$. The protease Stubble $(\mathrm{Sb})$ mediates degradation of aECM components such as the ZP-domain protein $\mathrm{Dp}$, allowing convergent extension of the underlying epithelium and wing elongation ${ }^{56}$. Evolutionary changes in appendage morphology may also reflect changes in aECM function: modern-day two-winged flies evolved from four-winged ancestors, with the vestigial posterior wings now functioning as balancing organs (halteres). The HOX transcription factor Ultrabithorax (Ubx) represses wing development and promotes haltere development, in part by repression of the aECM proteases $\mathrm{Sb}$ and $\mathrm{Np}$, resulting in failure to degrade $\mathrm{Dp}$ and thereby preventing aECM remodeling and wing extension ${ }^{28}$. Development of another morphological novelty, the posterior lobe of D. melanogaster male genitalia, is also regulated by expanded expression of the aECM component Dp, revealing variation in aECM expression as a pathway of morphogenetic evolution ${ }^{57}$.

\section{Patterning the aECM of the vertebrate inner ear}

The function of the mammalian inner ear rests on a set of mechanosensory epithelia and associated aECMs that form highly organized 3D structures known in mammals as the cupula, the otoconial membrane, and the tectorial membrane (TM) (Figure $1 \mathrm{~d})^{58}$. The TM is an extended ribbon-like aECM overlying the sensory epithelium of the cochlea (the spiral organ of Corti). It is the most complex inner ear aECM and plays multiple roles in sensory transduction. Much knowledge of inner ear aECMs has come from genetic studies of deafness or other inner ear disorders in humans, mice, or zebrafish ${ }^{59,60}$. These and other studies identified key components of the inner ear aECMs, including collagens (primarily types II, V, IX, and $\mathrm{XI}$ ) and non-collagenous glycoproteins, including the secreted mucin-like otogelins and the ZP-domain-containing $\alpha$ - and $\beta$-tectorins ${ }^{30}$. Mutations in $\alpha$-tectorin are a common cause of non-syndromic hearing loss, displaying dominant or recessive effects depending on the type of mutation and domain affected.

The TM forms a "roof" between ridges of the sensory epithelium (see Figure 1d). At its medial edge, the TM is anchored to the apical surface of the epithelium via the GPI-anchored protein otoancorin; at its lower lateral edge, the TM contacts the apical stereocilia of three rows of sensorimotor outer hair cells (OHCs). Recent genetic and morphological analysis has revealed that otogelin, otogelin-like, and the membrane-anchored stereocilin play interrelated roles in connecting the tips of $\mathrm{OHC}$ stereocilia to the $\mathrm{TM}^{46}$. While otogelin, otogelin-like, and stereocilin all localize independently within $\mathrm{OHC}$ hair bundles, loss of any one protein disrupts the distribution of the other two, suggesting interdependent roles in TM-OHC attachment.

The TM has been thought to have a primarily mechanical role, both by virtue of its direct connection to OHC stereocilia and via effects on fluid flow in the endolymph of the cochlea ${ }^{61}$. Recent evidence suggests the TM may also regulate the ionic environment surrounding the stereocilia. Fluorescence imaging revealed that the TM had elevated levels of $\mathrm{Ca}^{2+}$ compared to surrounding endolymph; loud sounds decrease the concentration of $\mathrm{TM} \mathrm{Ca}^{2+}$, reducing auditory sensitivity ${ }^{62}$. It is not yet known how the TM regulates $\mathrm{Ca}^{2+}$; however, this study suggests that aECMs might have additional unappreciated roles in extracellular calcium flux.

Ultrastructural analysis has revealed the remarkably complex spatial organization of the inner ear aECMs. The mature TM contains multiple structurally distinct layers and regions ${ }^{63}$ as well as other less well-understood structures formed transiently during development ${ }^{64}$. Recent ultrastructural analyses of otoconia or otoliths have also yielded insights into how the aECM regulates biomineralization ${ }^{65}$ and are revealing structural changes in the TM during aging and age-related hearing loss ${ }^{66}$.

The TM in mice develops gradually in late embryogenesis and early postnatal development; in its early stages, the TM is largely composed of the $\alpha$ - and $\beta$-tectorins, followed by oriented collagen fibrils ${ }^{67}$. Orientation of the collagen fibrils in the various TM layers is controlled by signals from the epithelium, as planar cell polarity defects in the epithelium disrupt collagen fibril organization ${ }^{67}$. The fine structure of the TM has been thought to arise largely from self-organization in the extracellular space, but recent work suggests that both the membrane-anchored and the secreted forms of $\alpha$-tectorin are required for organization of the $\mathrm{TM}^{31}$. $\alpha$-tectorin is GPI anchored and recruits collagen fibrils that support the formation of the TM at the cell surface. Subsequent release of $\alpha$-tectorin by cleavage of the GPI anchor allows the organization of collagens into a multilayered TM, suggesting a model in which the TM develops by "3D printing" of successive layers on the cell surface concomitant with release of the previously patterned layer.

\section{Remaining questions and future directions}

In summary, recent studies have expanded our understanding of aECM biogenesis and function across multiple model organisms and have begun to highlight shared structural and functional principles. With a comprehensive aECM parts list in hand, a clear future goal will be systematic analysis of expression, along the lines of the basement membrane toolkit recently generated for $C$. elegans ${ }^{68}$. In comparison to the protein components of aECM, a key knowledge gap remains the composition and assembly of extracellular lipid layers such as the epicuticle and envelope. High-resolution analytical approaches such as secondary ion mass spectrometry (SIMS) may offer fresh ways to address this problem ${ }^{69}$. Analysis of aECM assembly 
continues to rely on in vivo studies, although a long-term goal remains the development of in vitro reconstitution assays for aECM factors. Such assays could generate a better understanding of the interplay between cell-based templating and self-organization in aECM patterning. Improved mechanistic understanding of aECMs could shed light on the complexities of the genotype-phenotype interaction in studies of hearing loss related to TM dysfunction. Finally, although recent work has begun to reveal signaling between aECMs and internal tissues, more studies will be required to understand these pathways at mechanistic levels.

\section{Acknowledgements}

We apologize to authors whose work could not be cited for reasons of space. We thank Yishi Jin (Section of Neurobiology, Division of Biological Sciences, University of California, San Diego , La Jolla, CA, USA ), Jen Jin (Section of Neurobiology, Division of Biological Sciences, University of California, San Diego, La Jolla, CA, USA), and Mark Metzstein (Department of Human Genetics, University of Utah, Salt Lake City, UT, USA) for helpful comments and the reviewers for constructive suggestions.
1. Walma DAC, Yamada KM: The extracellular matrix in development. Development. 2020; 147(10): dev175596. PubMed Abstract | Publisher Full Text | Free Full Text

2. Fidler AL, Darris CE, Chetyrkin SV, et al:: Collagen IV and basement membrane at the evolutionary dawn of metazoan tissues. eLife. 2017; 6 e24176.

PubMed Abstract | Publisher Full Text | Free Full Text Faculty Opinions Recommendation

3. Dong B, Hayashi S: Shaping of biological tubes by mechanical interaction of cell and extracellular matrix. Curr Opin Genet Dev. 2015; 32: 129-34. PubMed Abstract | Publisher Full Text

4. Cohen JD, Sundaram MV: C. elegans apical extracellular matrices shape epithelia. J Dev Biol. in press. 2020; 8(4): 23. PubMed Abstract | Publisher Full Text | Free Full Text

5. Plaza S, Chanut-Delalande H, Fernandes I, et al.: From A to Z: Apical structures and zona pellucida-domain proteins. Trends Cell Biol. 2010; 20(9): 524-32. PubMed Abstract | Publisher Full Text

6. Chisholm AD, Xu S: The Caenorhabditis elegans epidermis as a model skin. II: Differentiation and physiological roles. Wiley Interdiscip Rev Dev Biol. 2012 1(6): 879-902.

PubMed Abstract | Publisher Full Text | Free Full Text

7. Lažetić V, Fay DS: Molting in C. elegans. Worm. 2017; 6(1): e1330246. PubMed Abstract | Publisher Full Text | Free Full Text

8. Labouesse M: Role of the extracellular matrix in epithelial morphogenesis: A view from C. elegans. Organogenesis. 2012; 8(2): 65-70. PubMed Abstract | Publisher Full Text | Free Full Text

9. Cohen JD, Sparacio AP, Belfi AC, et al.: A multi-layered and dynamic apical extracellular matrix shapes the vulva lumen in Caenorhabditis elegans. eLife. 2020; 9: e57874.

PubMed Abstract | Publisher Full Text | Free Full Text

10. Teuscher AC, Jongsma E, Davis MN, et al: The in-silico characterization of the Caenorhabditis elegans matrisome and proposal of a novel collagen classification. Matrix Biology Plus. 2019; 1: 100001. Publisher Full Text | Faculty Opinions Recommendation

11. Weadick CJ: Molecular Evolutionary Analysis of Nematode Zona Pellucida (ZP) Modules Reveals Disulfide-Bond Reshuffling and Standalone ZP-C Domains. Genome Biol Evol. 2020; 12(8): 1240-55. PubMed Abstract | Publisher Full Text | Free Full Text

12. Cohen JD, Flatt KM, Schroeder NE, et al:: Epithelial Shaping by Diverse Apical Extracellular Matrices Requires the Nidogen Domain Protein DEX-1 in Caenorhabditis elegans. Genetics. 2019; 211(1): 185-200. PubMed Abstract | Publisher Full Text | Free Full Text

13. Zhang Z, Bai M, Barbosa GO, et al.: Broadly conserved roles of TMEM131 family proteins in intracellular collagen assembly and secretory cargo trafficking. Sci Adv. 2020; 6(7): eaay7667. PubMed Abstract | Publisher Full Text | Free Full Text | Faculty Opinions Recommendation

14. Noble LM, Miah A, Kaur T, et al.: The Ancestral Caenorhabditis elegans Cuticle Suppresses rol-1. G3 (Bethesda). 2020; 10(7): 2385-95. PubMed Abstract | Publisher Full Text | Free Full Text | Faculty Opinions Recommendation

15. Kelley M, Yochem J, Krieg M, et al:: FBN-1, a fibrillin-related protein, is required for resistance of the epidermis to mechanical deformation during C. elegans embryogenesis. eLife. 2015; 4: e06565. PubMed Abstract | Publisher Full Text | Free Full Text | Faculty Opinions Recommendation

16. Vuong-Brender TTK, Suman SK, Labouesse M: The apical ECM preserves embryonic integrity and distributes mechanical stress during morphogenesis. Development. 2017; 144(23): 4336-49.

PubMed Abstract | Publisher Full Text | Free Full Text

17. Mancuso VP, Parry JM, Storer L, et al.: Extracellular leucine-rich repeat proteins are required to organize the apical extracellular matrix and maintain epithelial junction integrity in C. elegans. Development. 2012; 139(5): 979-90. PubMed Abstract | Publisher Full Text | Free Full Text

18. Forman-Rubinsky R, Cohen JD, Sundaram MV: Lipocalins Are Required for Apical Extracellular Matrix Organization and Remodeling in Caenorhabditis elegans. Genetics. 2017; 207(2): 625-42. PubMed Abstract | Publisher Full Text | Free Full Text

19. Flatt KM, Beshers C, Unal C, et al.: Epidermal Remodeling in Caenorhabditis elegans Dauers Requires the Nidogen Domain Protein DEX-1. Genetics. 2019; 211(1): 169-83.

PubMed Abstract | Publisher Full Text | Free Full Text | Faculty Opinions Recommendation

20. Low IIC, Williams CR, Chong MK, et al:: Morphogenesis of neurons and glia within an epithelium. Development. 2019; 146(4): dev171124. PubMed Abstract | Publisher Full Text | Free Full Text | Faculty Opinions Recommendation

21. Loer $\mathrm{CM}$, Calvo $\mathrm{AC}$, Watschinger $\mathrm{K}$, et al.: Cuticle integrity and biogenic amine synthesis in Caenorhabditis elegans require the cofactor tetrahydrobiopterin (BH4). Genetics. 2015; 200(1): 237-53. PubMed Abstract | Publisher Full Text | Free Full Text

22. Bada Juarez JF, O'Rourke D, Judge $P J$, et al: Lipodisqs for eukaryote lipidomics with retention of viability: Sensitivity and resistance to Leucobacter infection linked to C. elegans cuticle composition. Chem Phys Lipids. 2019; 222: 51-8. PubMed Abstract | Publisher Full Text

23. Abete-Luzi P, Fukushige T, Yun S, et al.: New Roles for the Heterochronic Transcription Factor LIN-29 in Cuticle Maintenance and Lipid Metabolism at the Larval-to-Adult Transition in Caenorhabditis elegans. Genetics. 2020; 214(3): 669-90.

PubMed Abstract | Publisher Full Text | Free Full Text

24. Mesbahi H, Pho KB, Tench AJ, et al:: Cuticle Collagen Expression Is Regulated in Response to Environmental Stimuli by the GATA Transcription Factor ELT-3 in Caenorhabditis elegans. Genetics. 2020; 215(2): 483-95. PubMed Abstract | Publisher Full Text | Free Full Text

25. Öztürk-Çolak A, Stephan-Otto Attolini C, Casanova J, et al.: Blimp-1 Mediates Tracheal Lumen Maturation in Drosophila melanogaster. Genetics. 2018; 210(2): 653-63.

PubMed Abstract | Publisher Full Text | Free Full Text

26.

Skouloudaki K, Christodoulou I, Khalili D, et al:: Yorkie controls tube length and apical barrier integrity during airway development. J Cell Biol. 2019; 218(8): 2762-81.

PubMed Abstract | Publisher Full Text | Free Full Text |

Faculty Opinions Recommendation

27. Rosa JB, Metzstein MM, Ghabrial AS: An Ichor-dependent apical 
extracellular matrix regulates seamless tube shape and integrity. PLOS Genet. 2018; 14(1): e1007146.

PubMed Abstract | Publisher Full Text | Faculty Opinions Recommendation

28. Diaz-de-la-Loza MDC, Loker R, Mann RS, et al.: Control of tissue morphogenesis by the HOX gene Ultrabithorax. Development. 2020; 147(5): dev184564.

PubMed Abstract | Publisher Full Text | Free Full Text |

Faculty Opinions Recommendation

29. Itakura Y, Inagaki S, Wada H, et al.: Trynity controls epidermal barrier function and respiratory tube maturation in Drosophila by modulating apical extracellular matrix nano-patterning. PLOS One. 2018; 13(12): e0209058. PubMed Abstract | Publisher Full Text | Free Full Text | Faculty Opinions Recommendation

30. Goodyear RJ, Richardson GP: Structure, Function, and Development of the Tectorial Membrane: An Extracellular Matrix Essential for Hearing. Curr Top Dev Biol. 2018; 130: 217-44.

PubMed Abstract | Publisher Full Text

31. Kim DK, Kim JA, Park J, et al.: The release of surface-anchored $\alpha$-tectorin, an apical extracellular matrix protein, mediates tectorial membrane organization. Sci Adv. 2019; 5(11): eaay6300.

PubMed Abstract | Publisher Full Text | Free Full Text |

Faculty Opinions Recommendation

32. Andrés $\mathrm{M}$, Turiégano $\mathrm{E}$, Göpfert $\mathrm{MC}$, et al:: The extracellular matrix protein artichoke is required for integrity of ciliated mechanosensory and chemosensory organs in Drosophila embryos. Genetics. 2014; 196(4): 1091-102. PubMed Abstract | Publisher Full Text | Free Full Text

33. Zhang Y, Qi L, Zhang H: TGF $\beta$-like DAF-7 acts as a systemic signal for autophagy regulation in C. elegans. J Cell Biol. 2019; 218(12): 3998-4006. PubMed Abstract | Publisher Full Text | Free Full Text | Faculty Opinions Recommendation

34. Madaan U, Faure L, Chowdhury A, et al:: Feedback regulation of BMP signaling by Caenorhabditis elegans cuticle collagens. Mol Biol Cell. 2020; 31(8): 825-32. PubMed Abstract | Publisher Full Text | Free Full Text

35. Madaan U, Yzeiraj E, Meade M, et al.: BMP Signaling Determines Body Size via Transcriptional Regulation of Collagen Genes in Caenorhabditis elegans. Genetics. 2018; 210(4): 1355-67. PubMed Abstract | Publisher Full Text | Free Full Text

36. Sellegounder D, Liu Y, Wibisono P, et al:: Neuronal GPCR NPR-8 regulates C. elegans defense against pathogen infection. Sci Adv. 2019; 5(11): eaaw4717. PubMed Abstract | Publisher Full Text | Free Full Text | Faculty Opinions Recommendation

37. Zuber R, Norum M, Wang Y, et al:: The ABC transporter Snu and the extracellular protein Snsl cooperate in the formation of the lipid-based inward and outward barrier in the skin of Drosophila. Eur J Cell Biol. 2018; 97(2): and out 101.

Pu-101.

38. Wang Y, Norum M, Oehl K, et al.: Dysfunction of Oskyddad causes Harlequin-type ichthyosis-like defects in Drosophila melanogaster. PLOS Genet. 2020; 16(1): e1008363.

PubMed Abstract | Publisher Full Text | Free Full Text |

Faculty Opinions Recommendation

39. Akiyama M: The roles of ABCA12 in epidermal lipid barrier formation and keratinocyte differentiation. Biochim Biophys Acta. 2014; 1841(3): 435-40. PubMed Abstract | Publisher Full Text

40. Ando T, Sekine S, Inagaki S, et al:: Nanopore Formation in the Cuticle of an Insect Olfactory Sensillum. Curr Biol. 2019; 29(9): 1512-1520.e6. PubMed Abstract | Publisher Full Text | Faculty Opinions Recommendation

41. Moussian B, Letizia A, Martínez-Corrales G, et al:: Deciphering the genetic programme triggering timely and spatially-regulated chitin deposition. PLOS Genet. 2015; 11(1): e1004939.

PubMed Abstract | Publisher Full Text | Free Full Text

42. Chandran RR, Scholl A, Yang Y, et al:: rebuff regulates apical luminal matrix to control tube size in Drosophila trachea. Biol Open. 2018; 7(9): bio036848. PubMed Abstract | Publisher Full Text | Free Full Text | Faculty Opinions Recommendation

43. Scholl A, O'Brien MJ, Chandran RR, et al.: The novel gene apnoia regulates Drosophila tracheal tube size. Dev Dyn. 2019; 248(6): 477-487. PubMed Abstract | Publisher Full Text | Faculty Opinions Recommendation

44. Zuber R, Shaik KS, Meyer F, et al:: The putative C-type lectin Schlaff ensures epidermal barrier compactness in Drosophila. Sci Rep. 2019; 9(1): 5374. PubMed Abstract | Publisher Full Text | Free Full Text | Faculty Opinions Recommendation

45. Drees L, Königsmann T, Jaspers MHJ, et al.: Conserved function of the matriptase-prostasin proteolytic cascade during epithelial morphogenesis.
PLoS Genet. 2019; 15(1): e1007882.

PubMed Abstract | Publisher Full Text | Free Full Text |

Faculty Opinions Recommendation

46. Avan P, Le Gal S, Michel V, et al.: Otogelin, otogelin-like, and stereocilin form links connecting outer hair cell stereocilia to each other and the tectorial membrane. Proc Natl Acad Sci U S A. 2019; 116(51): 25948-25957. PubMed Abstract | Publisher Full Text | Free Full Text | Faculty Opinions Recommendation

47. Hendriks GJ, Gaidatzis D, Aeschimann F, et al.: Extensive oscillatory gene expression during C. elegans larval development. Mol Cell. 2014; 53(3): 380-92. PubMed Abstract | Publisher Full Text | Faculty Opinions Recommendation

48. Dodd W, Tang L, Lone JC, et al:: A Damage Sensor Associated with the Cuticle Coordinates Three Core Environmental Stress Responses in Caenorhabditis elegans. Genetics. 2018; 208(4): 1467-82.

PubMed Abstract | Publisher Full Text | Free Full Text

49. Miao R, Li M, Zhang Q, et al.: An ECM-to-Nucleus Signaling Pathway Activates Lysosomes for C. elegans Larval Development. Dev Cell. 2020; 52(1): 21-37.e5.

PubMed Abstract | Publisher Full Text | Faculty Opinions Recommendation

50. Neville AC: Chitin lamellogenesis in locust cuticle. Q J Microsc Sci. 1965; 106(3) 269-86.

PubMed Abstract

51. Sviben S, Spaeker O, Bennet M, et al.: Epidermal Cell Surface Structure and Chitin-Protein Co-assembly Determine Fiber Architecture in the Locus Cuticle. ACS Appl Mater Interfaces. 2020; 12(23): 25581-90.

PubMed Abstract | Publisher Full Text | Free Full Text |

Faculty Opinions Recommendation

52. Hannezo E, Dong B, Recho P, et al:: Cortical instability drives periodic supracellular actin pattern formation in epithelial tubes. Proc Natl Acad Sci U S A. 2015; 112(28): 8620-5.

PubMed Abstract | Publisher Full Text | Free Full Text

53. Öztürk-Çolak A, Moussian B, Araújo SJ, et al:: A feedback mechanism converts individual cell features into a supracellular ECM structure in Drosophila trachea. eLife. 2016; 5: e09373.

PubMed Abstract | Publisher Full Text | Free Full Text

54. Hayashi S, Kondo T: Development and Function of the Drosophila Tracheal System. Genetics. 2018; 209(2): 367-80. PubMed Abstract | Publisher Full Text | Free Full Text

55. Tsarouhas V, Senti KA, Jayaram SA, et al.: Sequential pulses of apical epithelial secretion and endocytosis drive airway maturation in Drosophila. Dev Cell. 2007; 13(2): 214-25.

PubMed Abstract | Publisher Full Text | Faculty Opinions Recommendation

56. Diaz-de-la-Loza MDC, Ray RP, Ganguly PS, et al:: Apical and Basal Matrix Remodeling Control Epithelial Morphogenesis. Dev Cell. 2018; 46(1): 23-39.e5. PubMed Abstract | Publisher Full Text | Free Full Text | Faculty Opinions Recommendation

57. Smith SJ, Davidson LA, Rebeiz M: Evolutionary expansion of apical extracellular matrix is required for the elongation of cells in a novel structure. exife 2020 ; 9 : 55965 .

PubMed Abstract | Publisher Full Text | Free Full Text |

Faculty Opinions Recommendation

58. Goodyear RJ, Richardson GP: Extracellular matrices associated with the apical surfaces of sensory epithelia in the inner ear: Molecular and structura diversity. J Neurobiol. 2002; 53(2): 212-27.

PubMed Abstract | Publisher Full Text

59. Whitfield TT: Development of the inner ear. Curr Opin Genet Dev. 2015; 32 $112-8$.

PubMed Abstract | Publisher Full Text

60. Lundberg YW, Xu Y, Thiessen KD, et al:: Mechanisms of otoconia and otolith development. Dev Dyn. 2015; 244(3): 239-53. PubMed Abstract | Publisher Full Text | Free Full Text

61. Sellon JB, Ghaffari R, Freeman DM: The Tectorial Membrane: Mechanical Properties and Functions. Cold Spring Harb Perspect Med. 2019; 9(10): a033514. PubMed Abstract | Publisher Full Text | Free Full Text

62. Strimbu CE, Prasad S, Hakizimana $P$, et al.: Control of hearing sensitivity by tectorial membrane calcium. Proc Natl Acad Sci U S A. 2019; 116(12): 5756-64. PubMed Abstract | Publisher Full Text | Free Full Text | Faculty Opinions Recommendation

63. Andrade LR, Salles FT, Grati M, et al.: Tectorins crosslink type II collagen fibrils and connect the tectorial membrane to the spiral limbus. J Struct Biol. 2016; 194(2): 139-46.

PubMed Abstract | Publisher Full Text | Free Full Text

64. Lenoir M, Puel JL, Pujol R: Stereocilia and tectorial membrane development in the rat cochlea. A SEM study. Anat Embryol (Berl). 1987; 175(4): 477-87. PubMed Abstract | Publisher Full Text

65. Athanasiadou D, Jiang W, Reznikov N, et al:: Nanostructure of mouse otoconia 
J Struct Biol. 2020; 210(2): 107489. PubMed Abstract | Publisher Full Text

66. Bullen A, Forge A, Wright $A$, et al:: Ultrastructural defects in stereocilia and tectorial membrane in aging mouse and human cochleae. $J$ Neurosci Res. 2020; 98(9): 1745-63.

PubMed Abstract | Publisher Full Text

67. Goodyear RJ, Lu X, Deans MR, et al.: A tectorin-based matrix and planar cell polarity genes are required for normal collagen-fibril orientation in the developing tectorial membrane. Development. 2017; 144(21): 3978-89. PubMed Abstract | Publisher Full Text | Free Full Text
68. Keeley DP, Hastie E, Jayadev R, et al.: Comprehensive Endogenous Tagging of Basement Membrane Components Reveals Dynamic Movement within the Matrix Scaffolding. Dev Cell. 2020; 54(1): 60-74.e7.

PubMed Abstract | Publisher Full Text | Free Full Text |

Faculty Opinions Recommendation

69. Gilmore IS, Heiles S, Pieterse CL: Metabolic Imaging at the Single-Cell Scale: Recent Advances in Mass Spectrometry Imaging. Annu Rev Anal Chem (Palo Alto Calif). 2019; 12(1): 201-224.

PubMed Abstract | Publisher Full Text 